Jurnal Interpretasi Hukum |ISSN: 2746-5047

Vol. 2, No. 2 - Agustus 2021, Hal. 339-345| Tersedia online di https://www.ejournal.warmadewa.ac.id/index.php/juinhum

DOI: https://doi.org/10.22225/juinhum.2.2.3438.339-345

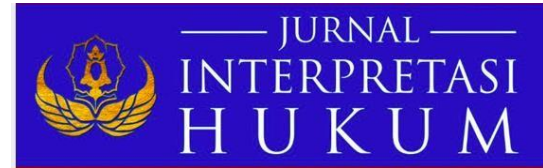

\title{
MEDIASI SEBAGAI ALTERNATIF PENYELESAIAN TINDAK PIDANA PENGANIAYAAN RINGAN YANG DILAKUKAN OLEH ANAK DI KABUPATEN GIANYAR
}

\author{
Dewa Gede Agung Getsumeda, Anak Agung Sagung Laksmi Dewi, I Made Minggu Widyantara \\ Fakultas Hukum Universitas Warmadewa, Denpasar, Bali \\ dewajoes15@gmail.com, laksmidewi@gmail.com, mademinggu21@gmail.com
}

\begin{abstract}
Abstrak
Bagi pihak yang ingin menyelesaikan sengketa tanpa pengadilan atau arbitrase, alternatif penyelesaian sengketa adalah pilihan. Pilihan ini sepenuhnya tergantung pada keinginan para pihak yang bersengketa. Terjadi perselisihan antara kedua pihak sehingga masing-masing pihak dapat memilih metode yang digunakan. Penelitian ini bertujuan untuk mengetahui pengaturan hukum tindak pidana penganiayaan ringan yang dilakukan oleh anak melalui mediasi dan untuk mengetahui akibat hukum jika tindak pidana penganiayaan ringan yang dilakukan oleh anak diselesaikan melalui mediasi. Tipe penelitian yang dipergunakan adalah penelitian hukum normatif. Data primer diperoleh dari tinjauan lapangan sedangkan data sekunder diperoleh dari artikel, peraturan perundang-undangan, dari bukubuku. Pengaturan hukum tindak pidana penganiayaan ringan yang dilakukan oleh anak melalui mediasi.Selain ketentuan tersebut pelanggaran ringan yang dapat diselesaikan melalui mediasi adalah tindak pidana yang dapat berupa kurungan atau kurungan paling lama 3 (tiga) bulan atau paling banyak Rp. 7.500,00 (Tujuh ribu lima ratus Rupiah). Pelanggaran pidana yang dilakukan oleh anak di bawah 8 tahun. Simpulan dari penelitian ini bahwa akibat hukum jika tindak pidana penganiayaan ringan yang dilakukan oleh anak diselesaikan melalui mediasi antara lain penyelesaiannya melalui musyawarah, perdamaian dan kesepakatan pelaku, korban dan keluarga sehingga menghasilkan winwin solution. Penyelesaian secara damai dasarnya adalah kesepakatan yang oleh para pihak dianggap baik dari segala jalan yang lain.
\end{abstract}

Kata Kunci: Anak, Mediasi, Tindak Pidana Penganiayaan Ringan.

\begin{abstract}
For parties who wish to resolve disputes without trial or arbitration, alternative dispute resolution is an option. This choice is entirely dependent on the wishes of the disputing parties. There is a dispute between the two parties so that each party can choose the method used. This study aims to determine the legal regulation of minor maltreatment committed by children through mediation and to find out the legal consequences if minor maltreatment crimes committed by children are resolved through mediation. The type of research used is normative legal research. Primary data is obtained from field reviews while secondary data is obtained from articles, laws and regulations, from books. In addition to these provisions, minor violations that can be resolved through mediation are criminal acts which can be in the form of confinement or imprisonment for a maximum of 3 (three) months or a maximum of Rp. 7,500.00 (Seven thousand five hundred). Criminal offenses committed by children under 8 years. The conclusion of this study is that the legal consequences if the crime of minor maltreatment committed by children is resolved through mediation, including settlement through deliberation, peace and agreement of the perpetrator, victim and family so as to produce a win-win solution. A peaceful settlement is basically an agreement that the parties consider good from all other ways.
\end{abstract}

Keywords: Children, Mediation, Minor Maltreatment 


\section{PENDAHULUAN}

Seorang anak remaja adalah bagian dari generasi muda yang merupakan generasi penerus cita-cita perjuangan bangsa. Remaja merupakan sumber daya manusia yang berkualitas yang dapat memimpin dan memelihara persatuan bangsa dalam kesatuan NKRI sesuai dengan Pancasila dan UUD 1945. Oleh karena itu diperlukan pembinaan yang terus menerus untuk menjaga kelangsungan hidup anak. Masyarakat terkadang menemukan bahwa perilaku anak muda menyimpang, sehingga banyak anak muda yang melakukan perbuatan melawan hukum tanpa mengetahui status sosial dan ekonominya. Selain itu, sebagian anak muda tidak berkesempatan memperoleh kesehatan fisik dan mental yang baik karena suatu sebab atau sebab lain. Perhatian spiritual dan psikologis. Dalam masyarakat, akibat kondisi diri yang tidak mencukupi, disengaja dan tidak disengaja, remaja seringkali mengadopsi perilaku atau perilaku yang merugikan diri sendiri dan masyarakat. Penyimpangan atau perilaku ilegal yang dikarenakan banyak faktor yaitu, efek jelek dari pesatnya kemajuan perkotaan, paradigm globalisasi pada bidang TIK, kemajuan ilmu TIK, serta perubahan gaya hidup dan gaya hidup orang tua tertentu. Perubahan. Masyarakat yang mempengaruhi nilai dan perilaku anak.

Disisi lain, anak yang belum mendapatkan kasih sayang, pengasuhan, bimbingan dan bimbingan dalam perkembangan sikap, perilaku, adaptasi dan pengawasan orang tua wali serta lingkungan yang kurang sehat dapat merugikan perkembangan pribadi seorang anak. Yang menjadi masalah sekarang adalah bagaimana jika perbuatan yang dilakukan oleh anak remaja tersebut menimbulkan kerugian terhadap kepentingan orang lain. Dalam hal yang demikian negara memiliki kewenangan untuk menjatuhkan pidana ataupun tindakan.

Wewenang untuk menjatuhkan pidana diserahkan kepada hakim. Untuk menegakkan hukum dan keadilan maka peranan dari badan peradilan sangat penting, menurut Pasal 1 butir 8 Kitab Undang-Undang Hukum Acara Pidana (KUHAP) bahwa Hakim adalah pejabat peradilan negara yang diberi wewenang oleh Undang-Undang untuk mengadili. Undang-Undang Peradilan Anak ditegaskan bagi anak di bawah umur 18 tahun yang melakukan tindak pidana, maka hakim dapat memilih salah satu dari beberapa alternatif yang terdapat dalam Pasal 23 ayat (2) dan Pasal 24 ayat (1) UndangUndang Nomor 11 Tahun 2012.

Bagi hakim yang menangani perkara pidana yang pelakunya adalah anak remaja, maka hakim dapat mengetahui sifat-sifat kejiwaan dari seorang anak remaja, Karena hakim bertanggung jawab untuk memeriksa dan menyelidiki secara menyeluruh mengapa anak-anak diabaikan (Erna Sofwan Syukrie, 1996:5).

Hakim dalam menjatuhkan putusan terhadap anak pelaku tindakan pidana disamping berdasarkan keyakinan hakim dan alat bukti yang sah, juga diperlukan pertimbangan yang sifatnya non yuridis misalnya sosiologi, psikologi dan sebagainya. Menurut Oemar Sena Adji bahwa seorang hakim memutus perkara pidana harus memperhatikan sifat seriusnya delik yang dilakukan keadaan yang menyertai perbuatan yang dihadapkan kepadanya (Oemar Sena Adji, 1984:8).

Hakim dalam memutuskan perakara anak diberi kebebasan untuk memilih beberapa alternatif yang telah diatur dalam pasal 23 ayat (2) dan pasal 24 ayat (1) Undang-Undang Nomor 11 Tahun 2012 tentang Sistem Peradilan Pidana Anak dan dalam menjatuhkan putusan tindak pidana disini hakim bebas menilai dan menentukan hal-hal atau keadaan yang dianggap paling tepat untuk menjatuhkan tindak pidana terhadap anak sedangkan kekeliruan hakim dalam mengambil keputusan dapat berakibat fatal bagi perkembangan anak itu sendiri.

Sejalan dengan perkembangan zaman, semua pihak saat ini cenderung menggunakan Alternative Dispute Resolution (APS), karena proses penyelesaian sengketa di pengadilan yang memakan waktu terlalu lama dianggap tidak praktis dan membutuhkan biaya yang tidak sedikit. Hal tersebut sesuai juga dengan pendapat $\mathrm{H}$. Desriza Ratna, yang menegaskan bahwa secara umum ada beberapa keuntungan yang diperoleh masyarakat bila menggunakan jalur nonlitigasi (di luar Pengadilan) atau Alternatif Penyelesaian Sengketa (APS), dalam menyelesaikan sengketa yang 
dihadapinya sebagai berikut : proses lebih cepat, biaya lebih murah, sifatnya informal, kerahasiaan terjamin, adanya kebebasan memilih pihak ketiga, dapat menjaga hubungan baik, bersifat final dan lain-lain (H. Desriza Ratna, 2012).

Bagi pihak yang ingin menyelesaikan sengketa tanpa pengadilan atau arbitrase, alternatif penyelesaian sengketa adalah pilihan. Pilihan ini sepenuhnya tergantung pada keinginan para pihak yang bersengketa. Di samping itu, penyelesaian masalah di Kabupaten Gianyar sering terjadi, sehingga penulis mudah untuk mendapatkan data sebagai bahan dalam penyusunan karya ilmiah ini.

Terjadi perselisihan antara kedua pihak sehingga masing-masing pihak dapat memilih solusi atas masalah tersebut. Semua pihak dapat memilih melalui pengadilan atau di luar pengadilan. Biasanya penyelesaian sengketa melalui pengadilan dilakukan atas prakarsa salah satu pihak. Pada saat yang sama, para pihak dapat menyelesaikan perselisihannya di luar pengadilan hanya jika kedua belah pihak setuju, dengan kata lain semua pihak ikhlas.

Menurut Andi Rahmah (2018) Tindak kekerasan fisik, seksual, psikis bahkan hingga penelantaran keluarga, menjadi salah satu masalah yang berlatarbelakang dari terjadinya penyimpangan visi dan misi dalam keluarga. Masalah-masalah ini membutuhkan penyelesaian secara hukum yang dimulai dari perangkat hukum yang memadai demi menghapus terjadinya kekerasankekerasan tersebut. Penyelesaian pada konflik - konflik yang terjadi di dalam masyarakat dapat dilakukan dengan dua pilihan, yaitu dengan jalur litigasi dan non-litigasi. Jalur litigasi merupakan cara penyelesaian masalah melalui jalur Pengadilan, sedangkan nonlitigasi merupakan cara penyelesaian masalah di luar Pengadilan (Cacuk Sudarsono, 2015). Pelaksanaan hukum dalam kehidupan masyarakat sehari-hari mempunyai arti yang sangat penting karena tujuan hukum adalah menciptakan keadilan kepastian dan memberikan kemanfaatan bagi masyarakat. Ketiganya itu bukan jargon semata dan harus bisa diwujudkan dan diimplementasikan pada pelaksanaan hukum itu sendiri. Keadilan dalam masyarakat hanya dapat diwujudkan kalau hukum dilaksanakan. Hukum itu harus dilaksanakan dan dipatuhi oleh semua orang dan semua orang itu harus diperlakukan sama di depan hukum (equality before the law). Apabila hukum tidak ditegakkan, maka ia tidak akan mempunyai makna dalam kehidupan masyarakat. Peraturan hukum yang demikian akan mati dengan sendirinya (James Hasudungan Hutajulu, 2015).

Dari paparan penjelasan diatas maka dirumuskan tujuan dari penelitian ini yaitu untuk mengetahui pengaturan hukum tindak pidana penganiayaan ringan yang dilakukan oleh anak melalui mediasi dan untuk mengetahui akibat hukum jika tindak pidana penganiayaan ringan yang dilakukan oleh anak diselesaikan melalui mediasi.

\section{METODE PENELITIAN}

Secara umum penelitian ini dilakukan untuk mengetahui Mediasi Sebagai Alternatif Penyelesaian Tindak Pidana Penganiayaan Ringan yang dilakukan oleh Anak di Kabupaten Gianyar Mematuhi hukum dan peraturan yang mengaturnya. Jenis penelitian yang digunakan dalam penelitian ini adalah penelitian hukum normatif.

\section{HASIL DAN PEMBAHASAN}

\section{Pengaturan Hukum Tindak Pidana Penganiayaan Ringan yang dilakukan oleh Anak Melalui Mediasi}

Mediasi biasanya dilakukan melalui prosedur sukarela, namun bisa juga dilakukan berdasarkan eksekusi kesepakatan atau kewajiban (regulasi) atau perintah pengadilan. Mengenai prosedur mediasi pengadilan, Pasal 7 UU Perma Nomor 02 Tahun 2003 mengatur Mediator dan para pihak wajib mengikuti prosedur penyelesaian sengketa melalui mediasi dalam Peraturan Mahkamah Agung ini. Proses mediasi pada dasarnya tidak bersifat terbuka untuk untuk umum, kecuali para pihak menghendaki lain. Tetapi, proses mediasi untuk sengketa publik, yaitu sengketa-sengketa lingkungn hidup, hak asasi manusia, perlindungan konsumen, dan perburuhan (yang melibatkan kepentingan banyak buruh), terbuka untuk umum. 
Dasar dari banyaknya tahapan pada proses mediasi sangat banyak. Lamanya proses juga sangat tergantung pada berbagai faktor, mulai dari substansi masalah hingga metode mediasi yang digunakan. Perma Nomor 2 Tahun 2003 dibedakan antara tahap pramediasi dan tahap mediasi. Untuk tahap paramediasi di pengadilan, yang penting untuk diperhatikan adalah Pasal 3, yang menentukan bahwa pada hari sidang pertama yang dihadiri kedua belah pihak, hakim mewajibkan para pihak yang berperkara agar lebih dahulu menempuh mediasi. Hakim berkewajiban untuk menunda persidangan perkara agar para pihak memiliki kesempatan untuk menengahi. Selain itu, hakim wajib menjelaskan prosedur dan biaya mediasi kepada para pihak.

Pasal 4 ayat (1) s/d (4) Perma Nomor 2 Tahun 2003 diatur jangka waktu pramediasi dan larangan bagi hakim sebagai mediator. Disebutkan bahwa hakim yang memeriksa suatu perkara, baik baik sebagai ketua majelis atau anggota majelis, dilarang bertindak sebagai mediator untuk perkara yang bersangkutan. Ketentuan masa pra-mediasi mengatur bahwa dalam satu hari kerja setelah sidang pertama, para pihak dan / atau pengacaranya harus berunding untuk memilih mediator dari daftar mediator yang dimilikinya. Seorang mediator yang tidak ada di pengadilan atau daftar pengadilan.

Jika para pihak atau pengacaranya tidak dapat mencapai kesepakatan tentang penggunaan mediator di dalam dan di luar daftar pengadilan dalam waktu satu hari kerja, para pihak wajib memilih mediator dari daftar mediator yang disediakan oleh pengadilan tingkat pertama. Demikian pula, jika para pihak tidak dapat setuju untuk memilih seorang mediator dari daftar yang diberikan oleh pengadilan dalam satu hari kerja, ketua kelompok berhak menunjuk seorang mediator dari daftar tersebut dan membuat keputusan.

Pengaturan pengaduan mediator bukan berasal dari pengadilan serta jangka waktunya ditentukan dalam pasal 5 ayat (1) s/d (4) yang menyatakan bahwa Proses mediasi yang menggunakan mediatordi luar daftar mediator yang dimiliki oleh pengadilan, berlangsung paling lama tiga puluh hari kerja.

Setelah waktu tiga puluh hari kerja terpenuhi para pihak wajib menghadap kembali pada hakim pada sidang yang ditentukan.Jika para pihak mencapai kesempatan,mereka dapat meminta penetapan dengan suatu akta perdamaian. Namun, jika para pihak berhasil mencapai kesepakatan yang tidak diwajibkan menjadi akta damai, pelapor wajib mencabut gugatan tersebut. Sebelum mediasi pengadilan, yang terpenting adalah mediator, dan kedua belah pihak berkewajiban untuk mematuhi semua prosedur penyelesaian sengketa yang diatur dalam PP Nomor 2 Tahun 2003.

Mediasi yang berhasil biasanya mengarah pada kesepakatan penyelesaian perselisihan. Setelah ditandatangani, hasil mediasi akan diingat dan dapat diimplementasikan sebagai kontrak atau kesepakatan. Namun, jika para pihak tidak bersedia menandatangani kesepakatan penyelesaian yang mengikat secara hukum, mereka memiliki kebebasan. Jangan lakukan itu. Padahal, kesepakatan hasil mediasi bisa dalam bentuk lisan maupun tertulis. Namun di Indonesia, kesepakatan hasil mediasi harus dalam bentuk tertulis. Ini berlaku untuk mediasi di dalam dan di luar pengadilan. UU No. 2 Tahun 2003 mengatur: "Jika kesepakatan dicapai melalui mediasi, para pihak dengan bantuan mediator wajib membuat kesepakatan tertulis dan ditandatangani oleh kedua belah pihak. Perjanjian tersebut harus memuat klausul penarikan atau a pernyataan lengkap dari kasus tersebut (Pasal 11 (1) dan (2))

Demikian pula, Pasal 6 Undang-Undang Nomor 30 tahun 1999 yang berkaitan dengan hasil mediasi dalam bentuk tertulis secara tegas menyebutkan usaha penyelesaian sengketa atau beda pendapat melalui mediator, dalam waktu paling lama 30 (tiga puluh) hari harus tercapai kesepakatan dalam bentuk tetulis yang ditandatangani oleh semua pihak yang terkait.

Jika mediasi dilaksanakan di luar pengadilan, terdapat kewajiban untuk mendaftarkan kesepakatan tertukis tersebut di pengadilan begeri dalam waktu paling lama 30 hari sejak penandatanganan (Pasal 6 ayat (7) Undang-Undang Nomor 30 Tahun 1999).Untuk menyelesaikan mediasi di penghadilan, hakim dapat mengukuhkan kesepakatan sebagai suartu akta perdamaian. 
Dalam Pasal 1 butir 1 Perma Nomor 02 Tahun 2003 disebutkan pkta perdamaian adalah dokumen kesepakatan yang merupakan hasil proses mediasi.

Pada tahap hasil proses mediasi, mediator biasanya membantu para pihak untuk menyusun kesepakatan; ketika membantu para pihak untuk menyiapkan kesepakatan mediasi tertulis, mediator harus fokus pada draf terlebih dahulu. Mediator harus memastikan bahwa para pihak sepenuhnya memahami draf perjanjian.

Perlunya penyusunan draf perjanjian diakomodasi dalam Pasal 11 ayat (3) Perma Nomor 02 Tahun 2003 bahwa sebelum para pihak menandatangani kesepakatan, mediator wajib memeriksa materi kesepakatan untuk menghindari adanya kesepakatan yang bertentangan dengan hukum. Kegiatan khusus terkait dengan proses mediasi tetap, yaitu melakukan review sengketa, menjelaskan proses mediasi kepada para pihak, membantu para pihak dalam pertukaran informasi dan tawarmenawar, serta membantu mereka menentukan dan mendaftarkan kesepakatan. Berbagai tahapan proses mediasi adalah sebagai berikut.

Biasanya para pihak sepakat untuk memilih mediator terlebih dahulu, atau mereka dapat meminta organisasi mediasi untuk membantu dalam pengangkatan atau penunjukan mediator. Selanjutnya para pihak dan mediator sepakat untuk menunjuk dan menandatangani perjanjian mediasi yang antara lain menyebutkan hal-hal yang bersifat rahasia dan biaya yang harus ditanggung. Kadangkadang mediasi dapat dimulai dan seorang mediator dapat ditunjuk oleh pengadilan. Hal ini melahirkan peraturan tentang bagaimana prosedur formal berlaku. Contoh: Untuk inisiasi mediasi (pra-mediasi) di pengadilan, berlaku ketentuan Pasal 4 (1) sampai (4) UU Tetap Nomor 02 Tahun 2003.

Dalam banyak kasus (terutama di luar negeri), ada pertemuan pendahuluan atau pertemuan jarak jauh (telekonferensi) di mana masalah prosedural disepakati. Biasanya, pada tahap ini, para pihak mengkomunikasikan posisinya secara tertulis (position paper) sebelum mediasi dilakukan.

Mediasi dapat dilakukan di mana saja yang dianggap nyaman dan menyenangkan oleh para pihak. Tempat pertemuannya cukup besar sehingga semua peserta bisa duduk di meja. Selain itu, semua pihak membutuhkan ruangan tersendiri untuk dijadikan "rumah" selama proses mediasi. Contoh: Pasal 15 (1). Disebutkan pada tanggal 2 Februari 2003.

\section{Akibat Hukum jika Tindak Pidana Penganiayaan Ringan yang dilakukan oleh Anak diselesaikan Melalui Mediasi}

Dalam mediasi, biasanya para pihak berkumpul. Mediator memberikan kata sambutan dan menjelaskan proses mediasi. Kemudian, mediator mengundang para pihak untuk menguraikan masalah dalam sengketa, membantu para pihak mengidentifikasi dan membahas masalah yang disengketakan, dan menguraikan beberapa cara untuk menyelesaikan masalah tersebut.

Pada dasarnya mediasi dapat digunakan untuk menangani sejumlah besar sengketa. Mediasi kini banyak digunakan dalam sengketa perdagangan, asuransi, kepemilikan perusahaan, industri, konstruksi (Pembangunan) dan bidang lainnya. Namun demikian, sulit untuk menentukan kapan suatu perselisihan sudah waktunya diselesaikan dengan mediasi.Untuk beberapa kasus, mediasi sudah siap segera setelah perselisihan timbul dan sebelum para pihak terlibat lebih dalam sehingga biaya yang dikeluarkan tidak terlalu besar untuk mengonsolidasikan posisi mereka. Tetapi, sering kali terjadi mediasi dikatakan sebelum siap, sehingga akhirnya para pihak berselisih sampai pada tahap yang hanya dapat diselesaikan melalui putusan hakim atu arbiter.Sebenarnya, di antara kedua titik ekstrim itu terdapat celah untuk mediasi. Praktik bisnis, ketika litigasi atau arbitrase akan dimulai, bahkan dalam proses persidangan yang sedang berlangsungpun, mediasi tetap dapat dilaksanakan secara bersama. Yang penting adalah kedua belah pihak siap untuk sampai pada sebuah penyelesaian melalui mediasi, dengan syarat mereka harus mampu mengendalikan mediasi, dengan syarat mereka harus 
mampu mengendalikan ambisinya dengan melakukan penilaian yang objektif atas keseluruhan situasi perselisihan.

Sesuai dengan uraian di atas, Susanti Adi Nugroho (2019) yaitu Mediasi merupakan salah satu bentuk alternatif penyelesaian sengketa di luar pengadilan. Pengaturan Penyelesaian Tindak Pidana Penganiayaan Ringan Yang Dilakukan Oleh Anak Melalui Mediasi di luar pengadilan diatur secara parsial, terbatas, dan gradasi pengaturannya diatur pada level di bawah undang-undang. Keterampilan nonlitigasi intinya penyelesaian sengketa hukum secara hukum di luar pengadilan melalui perdamaian.Pegangan penyelesaian sengketa adalah hukum, tetapi kontruksi penyelesaiannya disesuaikan dengan kehendak para pihak, agar para pihak merasa puas dengan penyelesaian seperti itu. Jadi, ujung penyelesaiannya adalah perdamaian, walaupun untuk mencapai hal itu bermacammacam seluas dan sejauh segala cara, model, prosedur yang menghiasi hukum sebagai pengangan pokok penyelesaian, yaitu seluas ruang lingkup aplikasi Keterampilan Non Litigasi (KNL) seperti diuraikan sebagai berikutnya.

Mediasi merupakan salah satu jalan yang ditempuh dalam upaya penyelesaian kasus penganiayaan ringan yang dilakukan oleh anak. Dengan mediasi maka para pihak akan duduk bersama untuk memecahkan masalah. Korban akan terlindungi dan terlibat dalam setiap tehapan pengambilan keputusan. Sehingga kerugian dan perlakuan yang dialaminya dapat terobati atau dipulihkan dengan konsekuensi yang harus dipenuhi oleh pelaku.Hal yang diputuskan dalam mediasi adalah benar-benar merupakan kebutuhan kedua belah pihak (Maulana Hasan Wadong, 2004).

Terkait dengan Dasar hukum penyelesaian sengketa Keterampilan Non Litigasi (KNL). Gatot Supramono, mengatakan bahwa Pasal 1338 KUHPerdata berbunyi semua perjanjian yang dibuat secara sah, berlaku sebagai undang-undang bagi yang membuatnya. Pasal 1266 KUHPerdata berbunyi: syarat batal dianggap selalu dicantumkan dalam persetujuan-persetujuan timbal balik, manakala salah satu pihak tidak memenuhi kewajibannya. Pasal 1851 s/d Pasal 1864 KUHPerdata tentang Perdamaian. Pasal 13 dan 14 HIR, perdamaian atas sengketa kecil-kecil di Desa oleh Kepala Desa. Pasal 130 HIR dan pasal 154 Rbg tentang usaha perdamaian, sebelum sengketa diperiksa di muka pengadilan. Undang-Undang Nomor 30 Tahun 1999 tentang Arbitrase dan Alternatif Penyelesaian sengketa.

Gatot Supramono (2000:30) Akibat hukum jika tindak pidana penganiayaan ringan yang dilakukan oleh anak diselesaikan melalui mediasi antara lain penyelesaiannya melalui musyawarah, perdamaian dan kesepakatan pelaku, korban dan keluarga sehingga menghasilkan win-win solution. Penyelesaian secara damai dasarnya adalah kesepakatan yang oleh para pihak dianggap baik dari segala jalan yang lain. Dianggap baik artinya bahwa walaupun jalan kesepakatan untuk menyelesaikan sengketa ini harus dilakukan dengan kesediaan untuk saling berkorban, maka pengorbanan itu dinilai paling wajar dan minimal pembiayaannya, jika dibanding dengan penyelesaian lewat jalur litigasi.

Dengan demikian dapat dijelaskan bahwa Penyelesaian secara mediasi pada dasarnya adalah kesepakatan yang oleh para pihak dianggap baik dari segala jalan yang lain. Diyakini bahwa metode yang baik adalah bahwa meskipun kesepakatan untuk menyelesaikan perselisihan ini harus dicapai dengan kesediaan untuk saling mengorbankan, pengorbanan ini dianggap paling masuk akal dan minimal pembiayaannya, jika dibanding dengan penyelesaian lewat jalur litigasi akibat hukumnya sesuai dengan keputusan mediasi.

\section{SIMPULAN DAN SARAN}

\section{Simpulan}

Berdasarkan uraian tersebut diatas maka simpulan dari penelitian ini adalah pngaturan hukum tindak pidana penganiayaan ringan yang dilakukan oleh anak melalui mediasi, antara lain : Surat Kepolisian Negara Republik Indonesia No. Pol : B / 3022 / XXI / 2009 / SDEOPS, tanggal 14 Desember 2009, 
menyangkut penanganan perkara melalui alternatif penyelesaian sengketa (ADR). Surat ini menjadi rujukan polisi untuk menyelesaikan kasus-kasus kejahatan kecil, contoh: 205.302.315.352.373.379.384.407 dan 482. Selain klausul di atas, tindak pidana ringan yang dapat diselesaikan melalui mediasi adalah tindak pidana yang dapat berupa kurungan atau kurungan. Denda sampai dengan 3 (tiga) bulan atau sampai dengan Rp. 7.500,00 (Tujuh ribu lima ratus rupiah). Anakanak di bawah 8 tahun bersalah atas pelanggaran pidana. Menurut pasal 11/2012 undang-undang pasal 7-8 sistem peradilan pidana anak, anak harus dipindahkan jika mereka melanggar hukum. Pemindahan tersebut merupakan tindak pidana yang terancam hukuman kurungan kurang dari 7 tahun dan bukan merupakan tindak pidana yang berulang. Konsekuensi hukumnya, melalui mediasi antara lain melalui negosiasi, perdamaian dan kesepakatan antara pelaku, korban dan keluarga, tindak pidana penganiayaan ringan yang dilakukan oleh anak tersebut dapat diselesaikan, sehingga tercapai win-win solution. Rekonsiliasi yang bersahabat pada dasarnya adalah kesepakatan yang dianggap baik oleh para pihak dalam segala hal. Cara yang baik diyakini bahwa meskipun kesepakatan untuk menyelesaikan perselisihan harus dicapai dengan kesediaan untuk saling berkorban, pengorbanan dianggap sebagai biaya yang paling masuk akal dan paling murah dibandingkan dengan penyelesaian melalui proses pengadilan.

\section{Saran}

Sesuai dengan simpulan tersebut diatas, dapat penulis sampaikan saran sebagai berikut:

Kepada Pemerintah, oleh karena masih terbatasnya hakim anak, penulis sarankan hendaknya segera menambah hakim anak di daerah masing-masing. Dengan cara ini, orang tua, masyarakat dan pemerintah dapat meningkatkan kesadaran akan tanggung jawab bersama atas masalah dan keprihatinan anak. Apalagi bagi para orang tua, mereka harus memberikan perhatian penuh terhadap perlindungan dan pengasuhan anaknya, agar tidak terjerumus ke dalam tindak pidana.

\section{DAFTAR PUSTAKA}

Adji, O. S. (1984). Hukum Hakim Pidana (Cet.2). Erlangga. Jakarta.

Hutajulu, J. H. (2015). Mediasi Penalsebagai Alternatif Penyelesaian Perkara Pencurian Ringan (Studi Di Polres Malang Kota). Jurnal Mahasiswa Fakultas Hukum Universitas Brawijaya.

Nugroho, S. A. (2019). Manfaat Mediasi Sebagai Alternatif Penyelesaian Sengketa. Prenada Media Group. Jakarta.

Rahmah, A. (2018). Mediasi Penal Sebagai Alternatif Penyelesaian Tindak Pidana Kekerasan Dalam Rumah Tangga. Urusprudentie, Vol.5 (2).

Ratna, H. D. (2012). Mediasi Non Litigasi Terhadap Sengketa Medik Dengan Konsep Win-Win Solution. PT. Elex Media Komputindo. Jakarta.

Sudarsono, C. (2015). Pelaksanaan Mediasi Penal Dalam Penyelesaian Tindak Pidana Penganiayaan. Unnes Law, Vol. 4(1).

Supramono, G. (2000). Hukum Acara Pengadilan Anak. Djambatan. Jakarta.

Syukrie, E. S. (n.d.). Perlindungan Hak-hak Anak dalam Undang-Undang Peradilan Anak, Diskusi Pembahasan RUU Peradilan Anak. Jakarta.

Wadong, M. H. (2004). Advokasi dan Hukum Perlindungan Anak. Grassindo. Jakarta. 